\title{
Syn-eruptive agglutination of kimberlite volcanic ash
}

\author{
David Haddock ${ }^{\alpha}$, Shukrani Manya ${ }^{\beta}$, Richard J. Brown ${ }^{\star \alpha}$, Thomas J. Jones $\gamma$, \\ Fabian B. Wadsworth ${ }^{\alpha}$, Katherine J. Dobson ${ }^{\delta}$, Thomas M. Gernon ${ }^{\epsilon}$ \\ ${ }^{\alpha}$ Department of Earth Sciences, Durham University, Durham, DH1 3LE, UK. \\ $\beta_{\text {Department of Geology, University of Dar es Salaam, Dar es Salaam, Tanzania. }}$

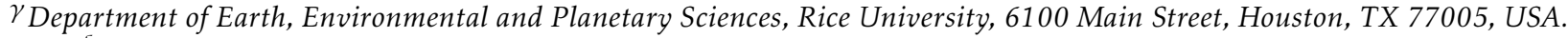 \\ ${ }^{\delta}$ Department of Civil and Environmental Engineering, University of Strathclyde, Glasgow, Scotland, G1 1XJ, UK. \\ ${ }^{\epsilon}$ School of Ocean and Earth Science, University of Southampton, SO14 3ZH, UK.
}

\begin{abstract}
Pyroclastic deposits of the Holocene Igwisi Hills kimberlite volcanoes, Tanzania, preserve unequivocal evidence for rapid, syn-eruptive agglutination. The unusual pyroclasts are composed of ash-sized particles agglutinated to each other by thin necks. The textures suggest the magma was disrupted into droplets during ascent. Collisions between particles occurred within a volcanic plume and on deposition within the conduit to form a weakly agglutinated, porous pyroclastic deposit. Theoretical considerations indicate that agglutination occurred over short timescales. Agglutinated clasts were entrained into weak volcanic plumes and deposited around the craters. Our results support the notion that agglutination can occur during kimberlite eruptions, and that some coherent, dense rocks in ancient kimberlite pipes interpreted as intrusive rocks could instead represent agglutinated pyroclastic rocks. Differentiating between agglutinated pyroclastic rocks and effusive or intrusive rocks in kimberlite pipes is important because of the potential effects that pyroclastic processes might have on diamond concentrations in deposits.
\end{abstract}

Keywords: Kimberlite; Welding; Agglutination; Volcanic ash; Pyroclasts

\section{INTRODUCTION}

The ascent and eruptive behaviour of ultrabasic and low silica magmas, such as kimberlites and carbonatites, remain relatively poorly constrained in comparison to more commonly erupted calc-alkaline magmas [see Carracedo Sánchez et al. 2015; Church and Jones 1994; Dawson et al. 1990; Russell et al. 2012; Russell et al. 2019; Sparks 2013; Sparks et al. 2006]. Kimberlite magmas, derived from low degrees of partial melting of mantle rocks, have repeatedly reached the Earth's surface throughout geologic time and their deposits can host economically important quantities of diamonds [Field and Scott Smith 1999; Mitchell 1986]. The composition of kimberlite melts has remained elusive due to the chemically reactive nature of the deposits, which are commonly highly altered [Mitchell 1986; Stripp et al. 2006; Willcox et al. 2015], and due to contamination by mantle- and crustal-derived material [Mitchell 1986]. Additionally the age of most kimberlite bodies (>30 Ma) means understanding of kimberlite eruptions has been deduced mostly through analysis of volcanic rocks preserved within the eroded conduits of ancient monogenetic volcanoes [Cas et al. 2008; Dawson 1971; Field and Scott Smith 1999; Hawthorne 1975; Skinner and Marsh 2004; Sparks et al. 2006]; rocks contained within surface edifices and extra-crater deposits

${ }^{*}$ Corresponding author: richard.brown3@durham.ac.uk are much rarer [Brown et al. 2012; Brown and Valentine 2013; Harvey et al. 2009]. Kimberlite pipes and edifices are variably composed of a wide range of pyroclastic deposits that reflect a range of eruption styles and emplacement temperatures, along with lavas, hypabyssal intrusions, and breccias of both volcanic and mass movement origin [Mitchell et al. 2019; Pell et al. 2018; Sparks 2013].

Agglutination, or welding, here defined as the high temperature adhesion of two or more juvenile pyroclasts, is a common process during volcanic eruptions and occurs within proximal pyroclastic fall deposits, in pyroclastic density current deposits, and in pyroclastic deposits contained within volcanic conduits [Quane and Russell 2005; Sparks and Wright 1979]. Welding of volcanic pyroclasts falls into a couple of dynamic regimes: gas escape and gas retention [Sparks et al. 1999]. The regime relevant to any given scenario depends principally on the origin of the stresses acting on the welding mass of particles, and the relative importance of inertia. In general, welding is time dependent, and may be driven by the pressure forcing the particles together (in the case of large welding systems), or by the capillary stresses at the particle contacts (in the case of small welding systems). In all cases, welding rates are strongly temperature dependent: hot particles with a low melt viscosity will weld quickly relative to cold, viscous particles [Vasseur et al. 2013; Wadsworth et al. 2016]. Agglutination results in a range of tex- 

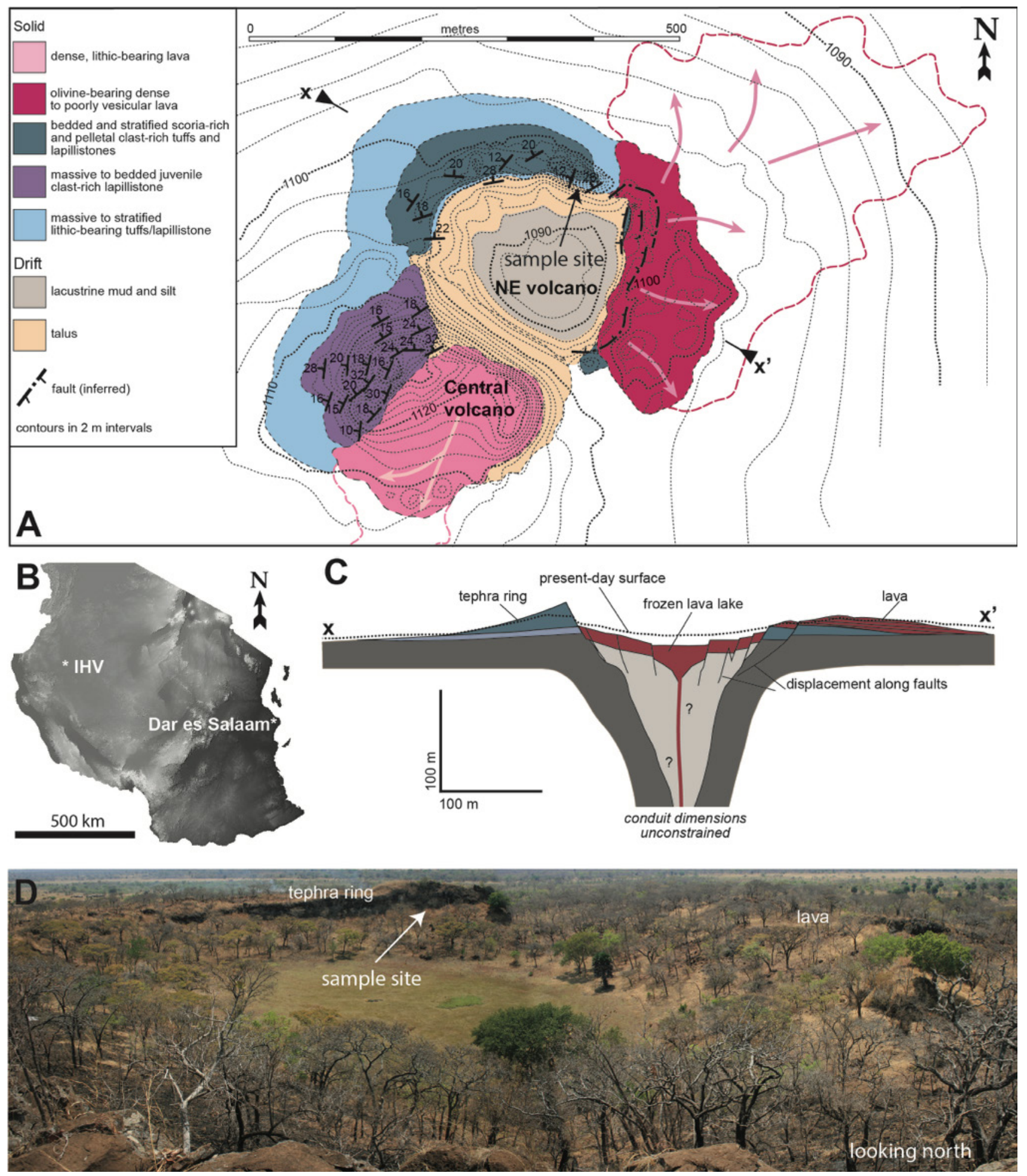

Figure 1: The NE volcano, Igwisi Hills volcano (IHV), Tanzania. [A] Geological map of the NE volcano of the IHV. The southeast volcano is not shown. For detailed descriptions of the deposits see Brown et al. [2012]. The SE volcano is not shown on map. [B] Location of the IHV in Tanzania. [C] Reconstructed cross-section across the NE volcano, excluding drift deposits. [D] Panorama looking north across the crater of the NE volcano along the profile marked $\mathbf{x}-\mathbf{x}^{\prime}$. Sample location for this study is marked. Images A, C, and D are modified from Brown et al. [2012]. 
tural features in deposits depending on the magnitude or extent of the process and it initiates with the adhesion of neighbouring melt particles or melt-coated particles at point contacts (necks). Agglutination can have a profound effect on the physical and structural properties of pyroclastic deposits through the reduction or removal of inter- and intra-clast pore space (e.g., vesicles), and by secondary flow (rheomorphism) and coalescence to revert back to a coherent melt [Quane and Russell 2005].

Pyroclastic rocks in a number of ancient kimberlite pipes have been interpreted as welded rocks based mainly on indirect geochemical and geological evidence [Brown et al. 2008a; Brown et al. 2009; Buse et al. 2011; Crawford et al. 2009; Nowicki et al. 2008; van Straaten et al. 2011]. These rocks may petrographically resemble intrusive or extrusive coherent igneous rocks (i.e. rocks that have crystallised from magma), but lack sharp boundaries, contain elevated abundances of lithic clasts and broken crystals, or form units that have geometries consistent with a pyroclastic origin [Brown et al. 2008a; Brown et al. 2009; Buse et al. 2011; Crawford et al. 2009; van Straaten et al. 2011]. Some were emplaced at sub-magmatic temperatures [Pell et al. 2015; Pell et al. 2018]. Conclusive evidence of welding, such as remnant clast outlines, agglutinated clasts, or welding foliations remain elusive [Cas et al. 2008]. Here, we document uniquely preserved kimberlite pyroclasts retrieved from the Holocene kimberlite Igwisi Hills volcanoes (IHV), Tanzania [Brown et al. 2012; Dawson 1994]. We present direct, unambiguous textural evidence for the agglutination of kimberlite pyroclasts, we show how this can inform on similar but less well-preserved rocks elsewhere, and then discuss the importance of identifying such deposits in kimberlite pipes.

\section{Geological setting}

The IHV are three small and closely-spaced monogenetic volcanoes that were first recognised in the 1950s [Bassett 1954; Dawson 1964; Fozzard 1956; Sampson 1953]. They are situated on the west of the Tanzanian craton, $800 \mathrm{~km}$ WNW of Dar es Salaam (Figure $1 \mathrm{~A}, \mathrm{~B})$. They represent the youngest known volcanic activity on the Tanzanian craton (10 ka, [Brown et al. 2012]), which previously experienced phases of kimberlite volcanism at around $189 \mathrm{Ma}$ [Davis 1977] and 53 Ma [Davis 1977; Gobba 1989; Haggerty et al. 1983]. They were emplaced through the granitic gneiss basement of the $2500 \pm 100$ Ma Dodoman system [Bell and Dodson 1981]. Reid et al. [1975] and Dawson [1994] considered that the Igwisi melts originated at $>110 \mathrm{~km}$ depth, and the mineralogy, major element and isotope chemistry of the IHV deposits have strong affinities with calcite-rich kimberlites (e.g. Benfontein sills, South Africa, [Dawson and Hawthorne 1973]; see also Mitchell [2008]; Willcox et al. [2015]).
The Igwisi magmas crystallised calcite, olivine, and a serpentine-like mineral that is interpreted to have replaced a silicate kimberlite glass in the groundmass (serpentine-X; see Willcox et al. [2015]; compare with Howarth and Büttner [2019]). Minor late-crystallising groundmass phases include apatite, phlogopite, monticellite, perovskite and spinel. Olivine xenocrysts recovered from IHV lavas exhibit rounded morphologies and rough, pitted surfaces [Brett et al. 2015; Jones et al. 2014]. These textural features have been attributed to rapid, turbulent subsurface transport wherein the mantle crystal cargo is subject to mechanical milling by particle-particle collisions [Jones et al. 2019a].

The IHV are aligned NE-SW and are composed of pyroclastic deposits from early explosive phases, and lavas from later effusive phases [Brown et al. 2012]. Here we focus on the most northerly volcano, imaginatively named the NE volcano (Figure 1B). This is a small maar-type volcano with a 200-m-wide, flat-bottomed crater that Brown et al. [2012] inferred is floored with a subsided lava lake, but is now covered by lacustrine sediments (Figure 1C and D). The crater is surrounded to the northwest by a low tephra ring and to the east by lavas. The southern side of the maar has been overtopped by pyroclastic deposits and lavas from the younger Central volcano [Brown et al. 2012]. The characteristics of the IHV pyroclastic deposits suggest weak explosive volcanic activity that probably lasted for a few days to weeks at each volcano. The deposits of these phases contain lithic clasts and they could have originated from initial phreatomagmatic eruptions. The IHV share many similarities to monogenetic volcanoes constructed during the eruption of basaltic magmas [Brown et al. 2012; Brown and Valentine 2013].

\section{Methods}

Samples were collected during a 10-day field campaign in 2009. We sampled lithic-rich coarse ash and fine lapilli fall deposits from the lowest exposed parts of the northerly tephra ring that surrounds the NE volcano. Thin sections were analysed in the Department of Physics, Durham University, using a Hitachi SU70 scanning electron microscope (SEM). A series of back-scattered electron (BSE) images were taken with a small $(\sim 10 \%)$ overlap using Oxford Instruments INCA software and were stitched together to produce large area mosaics. BSE images of pyroclasts were manually traced, exported as binary masks and then analysed using ImageJ software [Abràmoff et al. 2004] to obtain particle area, perimeter, major axis length, minor axis length, convex hull perimeter and area values. Convexity and solidity shape factors were calculated to describe both textural and morphological roughness [Liu et al. 2015]. Equation 1 and Equation 2 define the convexity $(C)$ and solidity $(S)$ shape factors: 


$$
C=\frac{P_{H}}{P_{P}}
$$

where $P_{P}$ is pyroclast perimeter and $P_{H}$ is the perimeter of the bounding convex hull; $C$ is used to quantify the small-scale concavities on the particle surface, referred to as textural roughness;

$$
S=\frac{A_{P}}{A_{H}}
$$

where $A_{P}$ is pyroclast area and $A_{H}$ is the area of the bounding convex hull. Here we use $S$ to quantify the roughness and irregularities on a particle scale (i.e. morphological roughness, [Liu et al. 2015]).

\section{Results}

The deposits are crudely stratified on a cm-scale and strata are defined predominantly by variations in the abundance of lithic clasts (Figure 2). The juvenile components reach $5 \mathrm{~mm}$ in diameter. Granitic and amphibolite lithic clasts, and crystals derived from them (Figure $2 \mathrm{~B}$ and Figure 3 ), are typically $<1 \mathrm{~cm}$ in diameter and account $5-40$ vol.\% of the sampled deposit.

The deposits contain a range of juvenile components and we divide them up into two types, depending on whether they contain a hard particle (a crystal or lithic fragment) as a core or not, with the caveat that most pyroclasts have been examined only in 2D. Type 1 clasts are composed of an olivine phenocryst, or a lithic fragment or xenocrysts (derived from a lithic clast) core, typically $<5 \mathrm{~mm}$ in diameter, encapsulated by a thin $(<100 \mu \mathrm{m})$ coating of crystallized kimberlite melt composed of microlitic crystals (olivine, spinel, titanomagnetite and calcite) phenocrysts, clays and serpentine (Figure 3A and 3B; Figure 4; see also Willcox et al. [2015]). The coatings vary in thickness around a single pyroclast from several tens to $\sim 150 \mu \mathrm{m}$. The surfaces are commonly irregular and lumpy due to the presence of crystals apparently encapsulated in groundmass that have agglutinated to the exteriors of the larger particles. Many of these smaller particles have diameters exceeding the thickness of the coating on the larger clasts (Figure 3). Coatings are partially missing around some clasts: this may have occurred either by melt-stripping within the eruption jet [Moss and Russell 2011] or during transportation from the field site.

Type 2 pyroclasts differ from Type 1 clasts by the absence of a large lithic or crystal core. Theyare dense to poorly vesicular, and are composed apparently entirely of crystallized kimberlite melt of similar composition to that of the Type 1 pyroclasts (Figure 3 and Figure 4G). Similar to Type 1 pyroclasts their exteriors are highly irregular giving them an amœboid morphology. Some contain irregular-shaped vesicles up to $1 \mathrm{~mm}$ in length, yielding vesicularity values of $<10-15$ vol.\% (Figure 4G).
The feature that is so far unique to the IHV is the sintering together of the pyroclasts to form delicate, submillimetre to millimetre-sized agglutinates (Figures 4 and 5). Agglutination is indicated by: (1) lumpy, irregular exteriors as a result of the partial coalescence of smaller $(<10 \mu \mathrm{m})$ ash particles onto larger particles (Figures 3 and 5), and; (2) the presence of necks of crystallised melt between larger ash particles (Figure 4). Each agglutinated particle is composed of 2 to $>40$ interconnected ash particles that are $50-3000 \mu \mathrm{m}$ in diameter (Figure 5). The necks are typically $20-100 \mu \mathrm{m}$ thick and 20-500 $\mu \mathrm{m}$ wide (Figure 4). Each ash particle is sintered by necks to several neighbouring particles, as seen in 2D (Figures 4 and 5). Some necks appear to have been broken in situ (Figure 4B and E). The agglutinates can exceed $10 \mathrm{~mm}$ in diameter, as imaged in 2D using a SEM. In 3D they are expected to be larger, consist of many more ash particles, and for ash particles to be sintered to many other adjacent particles. 2D shape analysis of Type 1 and Type 2 pyroclasts reveals a broad range of solidity values $(<0.6-0.9)$ and a broader range of convexity values $(0.3-0.95)$ (Figure 6). They are thus delicate, porous clasts formed through welding of point contacts of many smaller particles.

\section{Discussion}

\subsection{Agglutination processes}

During a kimberlite eruption, pyroclasts are generated by ductile break-up or by brittle fragmentation of the magma driven by rapid volatile gas expansion [Jones et al. 2019b; Moss and Russell 2011; Porritt and Russell 2012; Sparks et al. 2006], or by phreatomagmatic explosions [Brown et al. 2008b; Brown and Valentine 2013; Kurszlaukis and Lorenz 2017; Lorenz 1975; Porritt et al. 2013]. Low melt viscosities (0.1-10 Pas; [Sparks et al. 2006]) and efficient separation of gas and liquid phases are indicated by the droplet shape of kimberlite pyroclasts and the paucity of vesicles [e.g. Gernon et al. 2012]. Eruption temperatures for kimberlite magmas are in the range $1030-1170{ }^{\circ} \mathrm{C}$ [Fedortchouk 2004] and emplacement temperatures for non-welded kimberlite pyroclastic deposits are in the range 570$700{ }^{\circ} \mathrm{C}$ [Fontana et al. 2011; Gernon et al. 2009]. Minimum temperatures for welding, constrained by conodont geothermometry in rocks interpreted as welded kimberlite rocks, are in the range $700-950{ }^{\circ} \mathrm{C}$ [Pell et al. 2015; Pell et al. 2018]. Pyroclast morphology is controlled by the cooling rate or crystallisation rate, which in kimberlites is thought to be rapid [Porritt and Russell 2012]. The cooling or crystallisation rate controls competing processes such as surface tension-driven flow, vesiculation, and agglutination through collision or on deposition [Gernon et al. 2012; Moss and Russell 2011]. Dense or poorly vesicular kimberlite pyroclasts must deform predominantly by flow of thin melt rims 

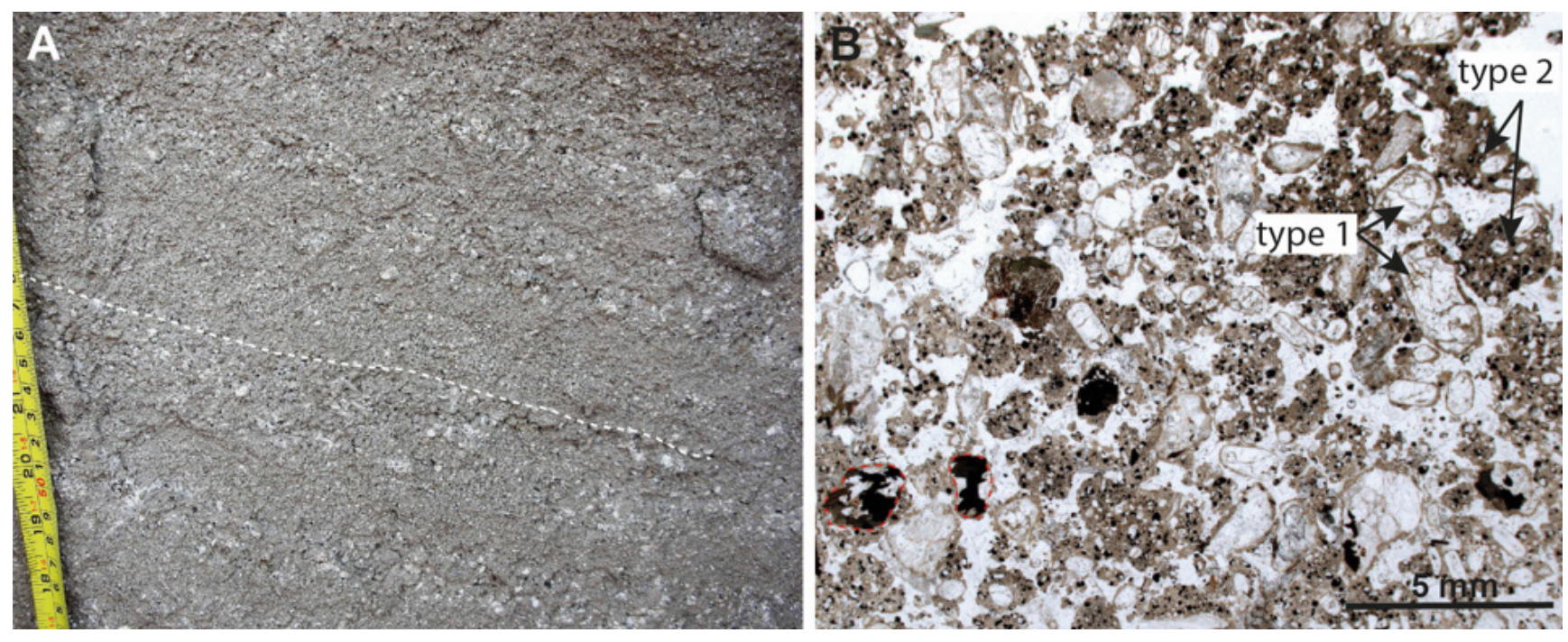

Figure 2: $[\mathrm{A}]$ Outcrop photo of the sampled pyroclastic deposits. Stratification is defined by variations in the abundance and size of lithic clasts. Dotted white line indicates bedding orientation. [B] Plane polarised light photomicrograph of the sampled deposits, showing Type 1 pyroclasts (each with a lithic or olivine crystal core) and Type 2 pyroclasts (no visible cores). Type 1 pyroclasts with lithic cores are outlined in red.
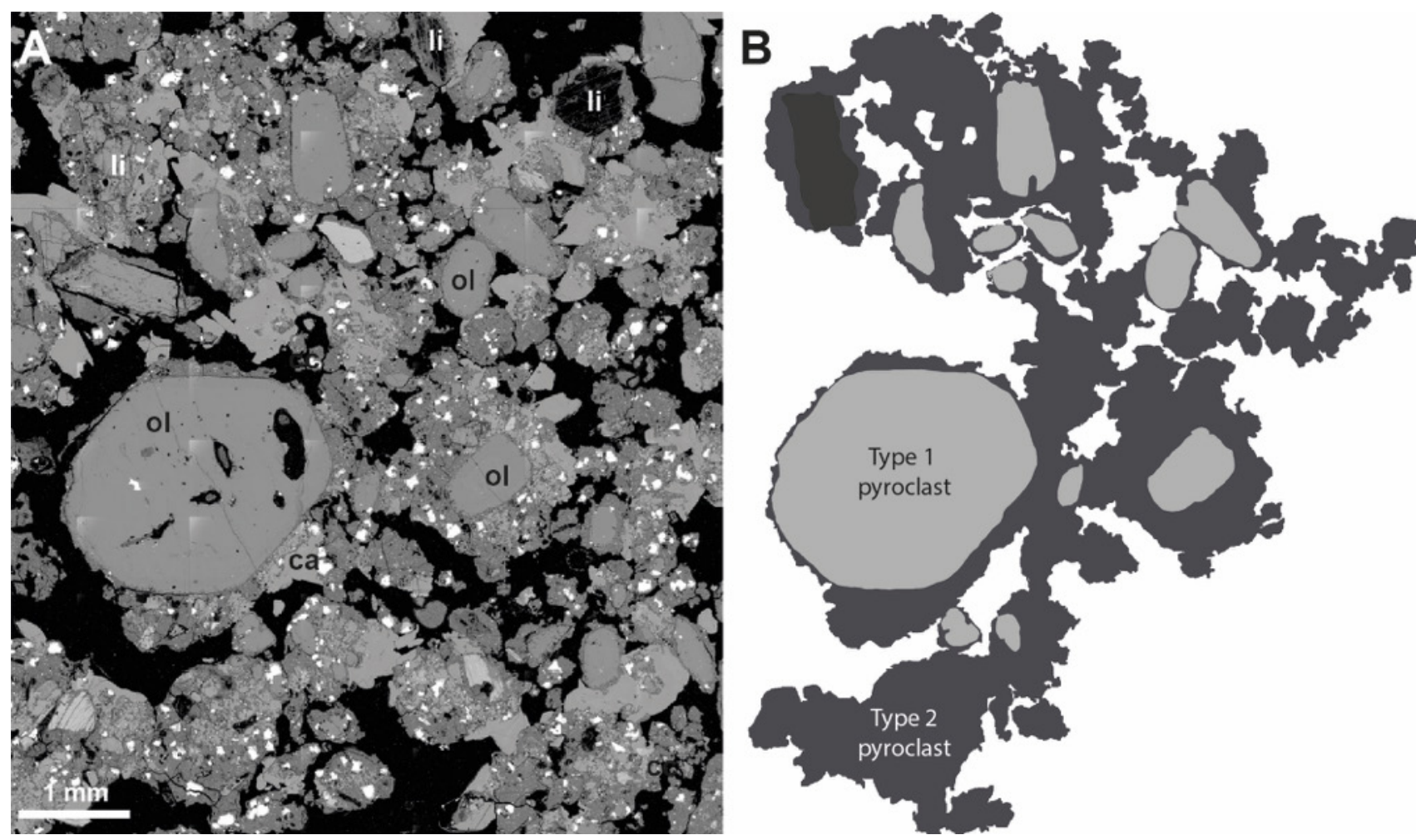

Figure 3: Typical features of agglutinated pyroclasts. [A] BSE image of large agglutinate within the studied tephra fall deposit. Pore space is black in the image. ol = olivine; $\mathrm{ca}=$ calcite cement; $\mathrm{li}=$ lithic clasts or lithicderived crystals [B] Outline of agglutinate in A showing pyroclasts consisting of large olivine crystals (grey) and crystallised juvenile melt (dark grey).

(around lithic or crystal cores), or of non-vesicular juvenile clasts, into inter-clast pore space. High volumes of rigid particles (crystals, lithic clasts) will resist deformation [Bouvard and Lange 1991].

The agglutinated textures indicate that the ash par- ticles had not reached the glass transition temperature $\left(T_{g}\right)$ by the time that they came into contact with each other, and had not fully crystallized. The necks were able to form by viscous relaxation of the local curvature at point contacts between particles, and resulted in 

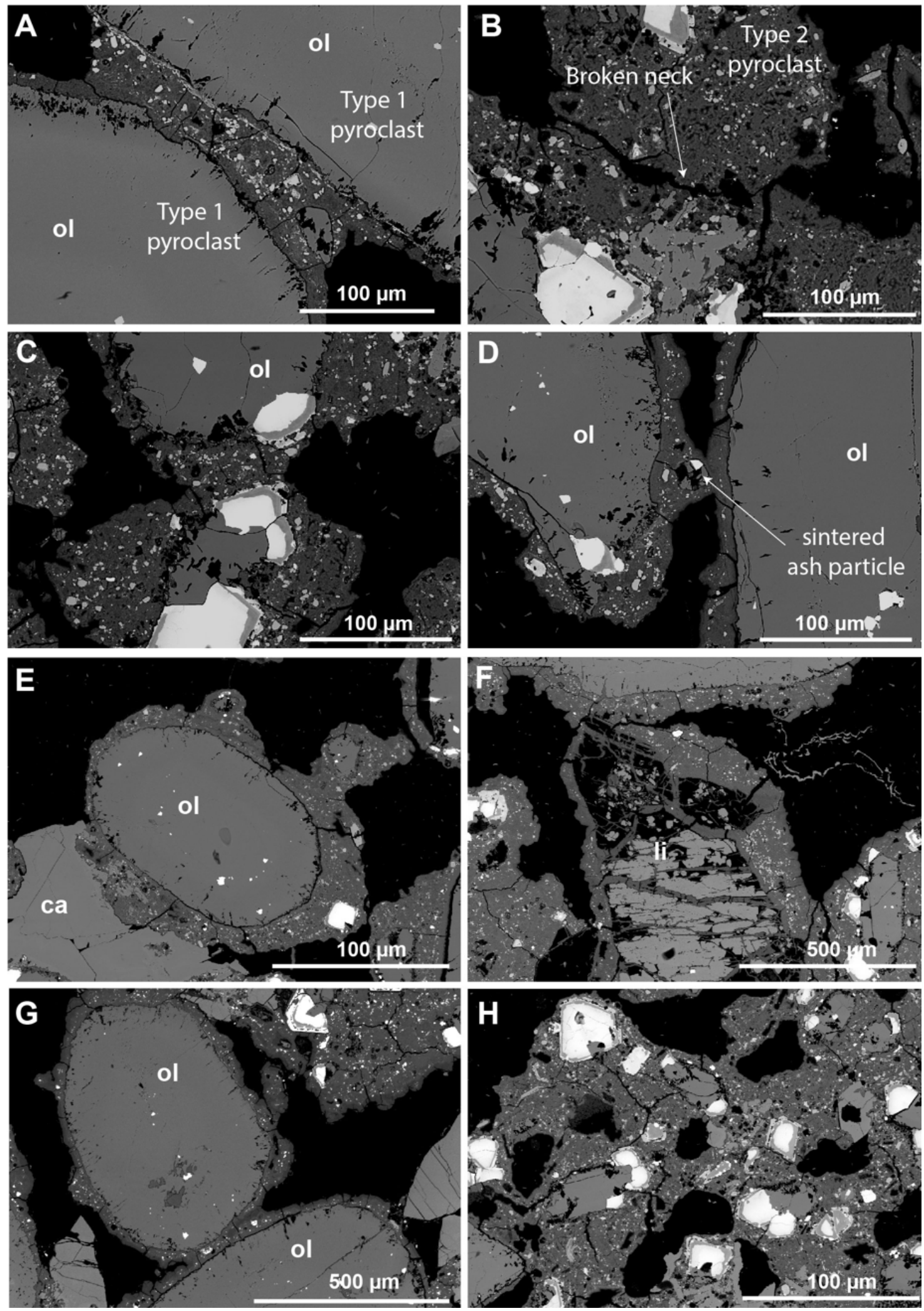

Figure 4: Examples of agglutinated pyroclasts. [A] Agglutinated neck between two groundmass coated olivine crystals (Type 1 pyroclasts). [B] Broken neck between two Type 2 pyroclasts. [C] Agglutinated neck between two Type 1 pyroclasts. [D] Thin agglutinated neck between two Type 1 pyroclasts (i.e. olivine crystal). [E] Type 1 pyroclasts with small agglutinated clasts on exterior and post-eruption calcite cement (ca). [F] and [G] Examples of thin agglutinated necks between pyroclasts. Lithic clast forms the core in the Type 1 pyroclast in [G]. [H] Type 2 pyroclast with small irregular vesicles. Bright white crystals are titanomagnetite with spinel rims [see Willcox et al. 2015]. 


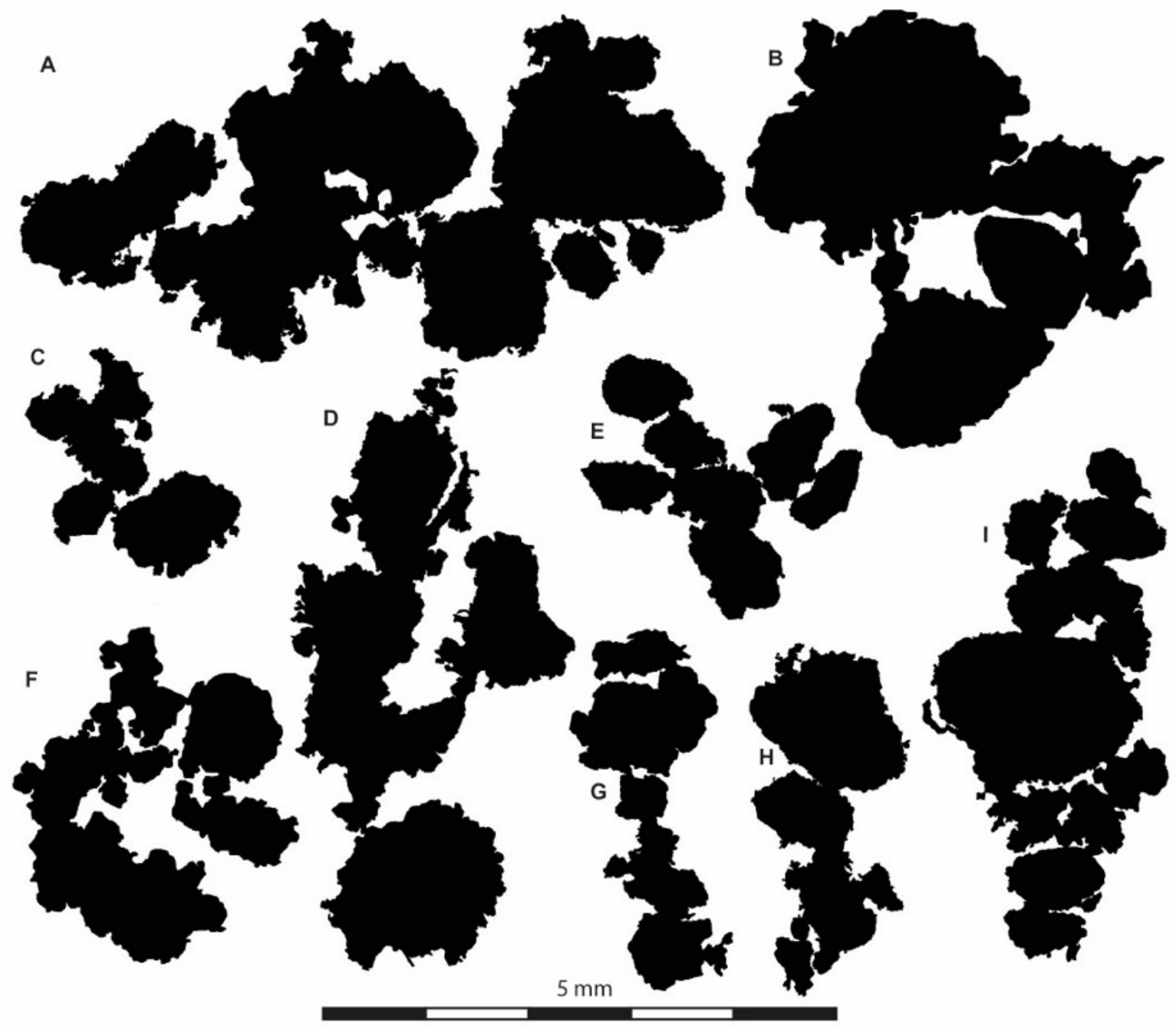

Figure 5: 2D masks of ash agglutinates derived from BSE images at $150 \times$ magnification.

a framework of agglutinated particles [see Wadsworth et al. 2016]. The short necks demonstrate that this process did not have time to finish before the sample either crossed $T_{g}$, or crystallized, preserving a partially agglutinated texture. This incomplete agglutination is consistent with the low solidity and convexity values of the pyroclasts, representing surface irregularities (Figure 6). Surface irregularities indicate that there was little or no surface smoothing under surface tension following neck-formation. Increased time above $T_{\mathrm{g}}$ would have increased neck widths: if this had occurred postdeposition the deposit would have become more fully welded, dense, and coherent, dependent on the ratio of melt to solid particles [e.g. Wadsworth et al. 2016]. The thin necks observed here indicate rapid crystallisation and limited viscous mobilisation of melt into inter-clast pore spaces.

Hot, coarse-grained pyroclasts (spatter and bombs) can agglutinate on deposition to form variably welded and agglutinated fall deposits during volcanic eruptions [e.g. Soriano et al. 2002; Sparks and Wright 1979;
Sumner et al. 2005]. The agglutination of hot ash particles upon fallout around the NE volcano can be ruled out because the particles would have cooled quickly to ambient temperature while settling through the atmosphere. Particles of similar size to the Igwisi pyroclasts $(<2 \mathrm{~mm})$ falling from Hawaiian lava fountains $(<500 \mathrm{~m}$ high) equilibrate with ambient temperatures $\left(25^{\circ} \mathrm{C}\right)$ in $<5$ s [Porritt et al. 2012]. This is well below the particle fallout time from a small eruption plume $\left(10^{3}-10^{4} \mathrm{~s}\right.$, assuming 1-3 $\mathrm{m} \mathrm{s}^{-1}$ ) [Wilson and Huang 1979] from a 2-km-high eruption, as inferred for the IHV [Brown et al. 2012]. Therefore, formation of the agglutinated pyroclasts must have occurred prior to deposition around the crater.

The textures of the pyroclasts reveal two stages of agglutination. We infer that the first occurred at temperatures above $T_{g}$ and resulted from small $(<100 \mu \mathrm{m})$ ash particles colliding with larger $(>1000 \mu \mathrm{m})$ meltcoated particles (Figure 7 ) in a manner similar to that proposed by Carracedo Sánchez et al. [2015] for some eruptions of lamproite magma. The second stage could 


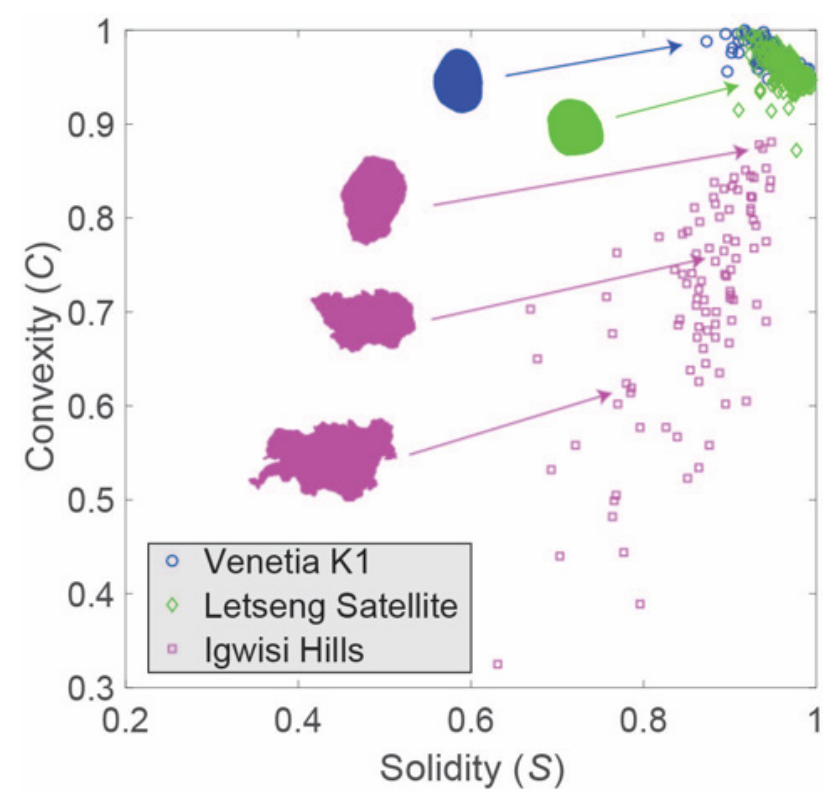

Figure 6: 2D Solidity and convexity shape factors for Igwisi Hills pyroclasts (Type 1 and Type 2 undifferentiated) alongside juvenile (pelletal) pyroclasts from the Letseng Satellite and Venetia K1 kimberlite [Gernon et al. 2012]. Particle outlines are not to scale.

have occurred concomitantly with the first stage leading to extra-vent fallout, or alternatively during waning eruption periods when gas exit velocities were too low to eject small pyroclasts from the conduit, and instead they accumulated within it, and agglutinated at point contacts (Figure 7). Transformation of molten IHV pyroclasts back to a liquid was inhibited by rapid groundmass crystallisation. We suggest that some of the welded deposits in the conduit were fragmented by later eruptive phases, and those fragments were entrained into weak eruption plumes and settled out around the crater to form the deposits sampled in this study. Larger fragments of these former conduit deposits have not yet been identified in the tephra ring probably because the agglutinates are texturally and visually similar to loose, non-agglutinated deposits of kimberlite ash (i.e. necks are only resolvable using SEM). Additionally, turbulent transport in an eruption plume and impacts on fallout would have caused granulation of the presumably fragile agglutinates [e.g. Jones and Russell 2017; Jones et al. 2017].

Given the insights discussed above, we can place constraints on the regime in which these partial agglutination events occurred based on dimensional arguments. First, when two melt particles or melt-coated crystal pellets collide, impact or capillary stresses arising from surface tension could dominate. These regimes are delineated by the Weber number We $=\rho u^{2} R / \Gamma$, where $\rho$ is the density of the melt particle, $u$ is the velocity of the impact, $R$ is the particle radius, and $\Gamma$ is the surface tension. If We $\gg 1$, then the impact ve- locity is high, and impact stresses dominate. Using $\rho=2000 \mathrm{~kg} \mathrm{~m}^{-3}, R=1 \mathrm{~mm}$ (Figure 3 ), $\Gamma=0.3 \mathrm{~N} \mathrm{~m}^{-1}$, we can estimate that the boundary between high and low Weber number behaviour occurs at $u=0.4 \mathrm{~ms}^{-1}$. Given that most explosive volcanic events eject particles at $10-100 \mathrm{~m} \mathrm{~s}^{-1}$ (lower limit from Sparks et al. [2006]), we estimate that most agglutination events occur in the high Weber number regime, where impact stresses dominate the interaction. Second, the Ohnesorge number $\mathrm{Oh}=\mu /(\sqrt{\rho R \Gamma})$, where $\mu$ is the viscosity, governs whether the interaction is resisted by viscous or inertial forces. Using the viscosity range given earlier, we find that kimberlite melts may straddle the regime divide of $\mathrm{Oh}=1$, with $0.13<\mathrm{Oh}<13$, consistent with the findings of Jones et al. [2019b].

Taken together, the discussion of the regimes of interaction given above, allow us to constrain the timescales involved in agglutination of particle-particle pairs. For the case of high velocity interactions (We $>1$ ) of particles with low viscosity $(\mathrm{Oh}<1)$ then the timescale of the interaction is approximately:

$$
\lambda_{u} \sim \frac{R}{u}
$$

and for the case of high-velocity interactions (We $>$ 1) of particles with high viscosity $(\mathrm{Oh}>1)$ then the timescale of the interaction is approximately:

$$
\lambda_{\mu} \sim \frac{\mu}{\rho u^{2}} .
$$

If we approximate the ejection velocities as impact velocities, then for $10-100 \mathrm{~m} \mathrm{~s}^{-1}$ impact velocities, we can estimate $0.01<\lambda_{u}<0.1 \mathrm{~s}$, and $10^{-9}<\lambda_{\mu}<10^{-5} \mathrm{~s}$. Because the particles are only poorly agglutinated, the quenching times had to have been similar to these timescale estimates. The impact velocities could be lower than this in the more realistic scenario that the particles are not colliding headon, and that they may instead collide obliquely. In this case, the interaction times will be longer, providing more time for the agglutination to occur and making it more likely that these textures would be observed. Either way, this suggests that the agglutination is extremely rapid and concomitant with cooling, similar to thermal spray industrial coating techniques [e.g. Pawlowski 2008].

\subsection{Comparison with other types of kimberlite pyro-} clasts

Juvenile kimberlite pyroclasts exhibit a wide range of shapes, from spherical to sub-spherical melt-coated crystals (pelletal clasts) through to amœboid and poorly vesicular ash and lapilli-sized particles. Spherical or sub-spherical juvenile pelletal clasts are common in kimberlite diatremes worldwide [Gernon et al. 2012; Mitchell 1986; Sparks et al. 2006]. They are typically composed of an olivine crystal encased in a thin, 
smooth layer of crystallised kimberlite melt [Mitchell 1986]. Shape analysis of representative juvenile pelletal clasts from two kimberlite pipes (Venetia K1, Republic of South Africa, and Letseng Satellite, Lesotho) reveal narrow ranges and high values of high convexity and high solidity (Figure 6). Their shapes indicate that their surfaces have structurally relaxed due to surface tension forces. Typically, they do not exhibit textural or morphological evidence for agglutination. This could result from either rapid crystallisation of melt prior to collision with other particles, or conversely due to extended flow of melt around agglutinated particles at temperatures above $T_{g}$ following collision, such that evidence for agglutination is erased (or cryptic). The shapes of pelletal clasts contrast with the IHV pyroclasts. The broad range of solidity values $(<0.6-0.9)$ and broader range of convexity values $(0.3-0.95)$ of the latter pyroclasts clearly result from agglutination and reflect primarily variations in the size and number of sintered small particles on the exteriors of the measured clasts.

Amœboid kimberlite pyroclasts have been described from a number of locations worldwide [e.g. Leckie et al. 1997; Mitchell 1986; Skinner and Marsh 2004]. They are irregular in shape with lumpy exteriors, and some show evidence for deformation against adjacent clasts [Leckie et al. 1997]. They are more closely similar to the pyroclasts described here, but as yet do not yet know of other deposits that exhibit such pervasive agglutination as displayed by the Igwisi deposits, but caution that textural evidence may be masked in ancient rocks by pervasive post-deposition chemical alteration [e.g. Afanasyev et al. 2014; Stripp et al. 2006].

\subsection{Significance of the agglutinated lapilli}

Dense, coherent kimberlite rocks at a number of mined kimberlite volcanoes have been interpreted as welded kimberlite pyroclastic rocks. This interpretation has been based variably on the presence of dispersed lithic clasts, gradations into demonstrably non-welded pyroclastic rocks and breccias, the presence of broken crystals, remnant inter-particle pore space, and on submagmatic emplacement temperatures [e.g. Brown et al. 2008a; Brown et al. 2009; Buse et al. 2011; Crawford et al. 2009; Pell et al. 2015; Pell et al. 2018, van Straaten 2008]. The distinctive geochemical characteristics of some dense coherent kimberlite rocks has also been proposed as evidence that they have lost fine-grained material through elutriation in an eruption jet, rather than being intrusive igneous rocks that crystallised in situ from a melt [Nowicki et al. 2008]. The IHV agglutinated pyroclasts provide unequivocal evidence for high temperature agglutination of juvenile kimberlite pyroclasts. We propose that they represent the start of a process that, if continued at sustained high temperatures, would have transformed the pyroclastic deposits into a liquid or a dense coherent rock. Coalescence of hot py- roclasts back into a liquid phase occurs during basaltic eruptions to form lavas and lava lakes and during some explosive eruptions high silica magmas to form lavalike ignimbrites [e.g. Andrews and Branney 2011; Ellis et al. 2015]. Some dense coherent rocks in the conduits of kimberlite volcanoes elsewhere that have been interpreted as hypabyssal intrusions could represent densely welded pyroclastic rocks that coalesced back to a liquid and then crystallised to become texturally indistinguishable from hypabyssal rocks or lavas.

The IHV agglutinated pyroclasts provide insight for several reasons: (1) They provide a robust template for interpreting similar but less well preserved rocks in the geologic record, as well as rocks that may be more densely welded and resemble coherent intrusive rocks. (2) They provide further constraints and evidence that could be used to understand the eruption dynamics of these and other similar magmas. (3) In general, they confirm that welding processes can occur during the eruption of a wide range of magma compositions and that the textures of welded rocks can differ significantly due to variations in magma composition, melt rheology, and vesicularity [see Brown et al. 2008a; van Straaten et al. 2011].

When magma is processed through a pyroclastic fountain or an eruptive jet, a portion of the erupted magma is lost through the coupling of fine ash particles with hot gas in a buoyant plume: dense, large particles released during fragmentation will become more concentrated in proximal welded rocks that accumulate at the base of fountains and jets relative to the erupting magma [Carey and Sparks 1986]. Ancient kimberlite volcanoes are the principal global source of diamonds [Field et al. 2008; Gurney et al. 2010] and the impact of this process on diamond concentrations in different rocks within a kimberlite volcano remains untested. One could speculate that agglutinated kimberlite pyroclastic rocks could contain higher concentrations of diamonds than co-emplaced intrusive rocks or lavas that were fed by magma with equal pre-eruption concentrations of diamonds, due to the loss of melt as fine particles during fragmentation of the magma. Additionally, recognising that subsurface apparently coherent rocks are not necessarily hypabyssal intrusions and instead could be welded pyroclastic rocks, could help inform resource evaluation during exploratory drilling phases of a kimberlite pipe.

\section{Conclusions}

Unique, well-preserved pyroclasts from the tephra ring around the $11 \mathrm{ka} \mathrm{NE}$ volcano of the kimberlite Igwisi Hills Volcanoes, Tanzania, provide the first compelling, unambiguous evidence for syn-eruptive agglutination of kimberlite volcanic ash particles. We infer that the magma was fragmented into droplets and melt-coated particles (crystals and lithic clasts) during 


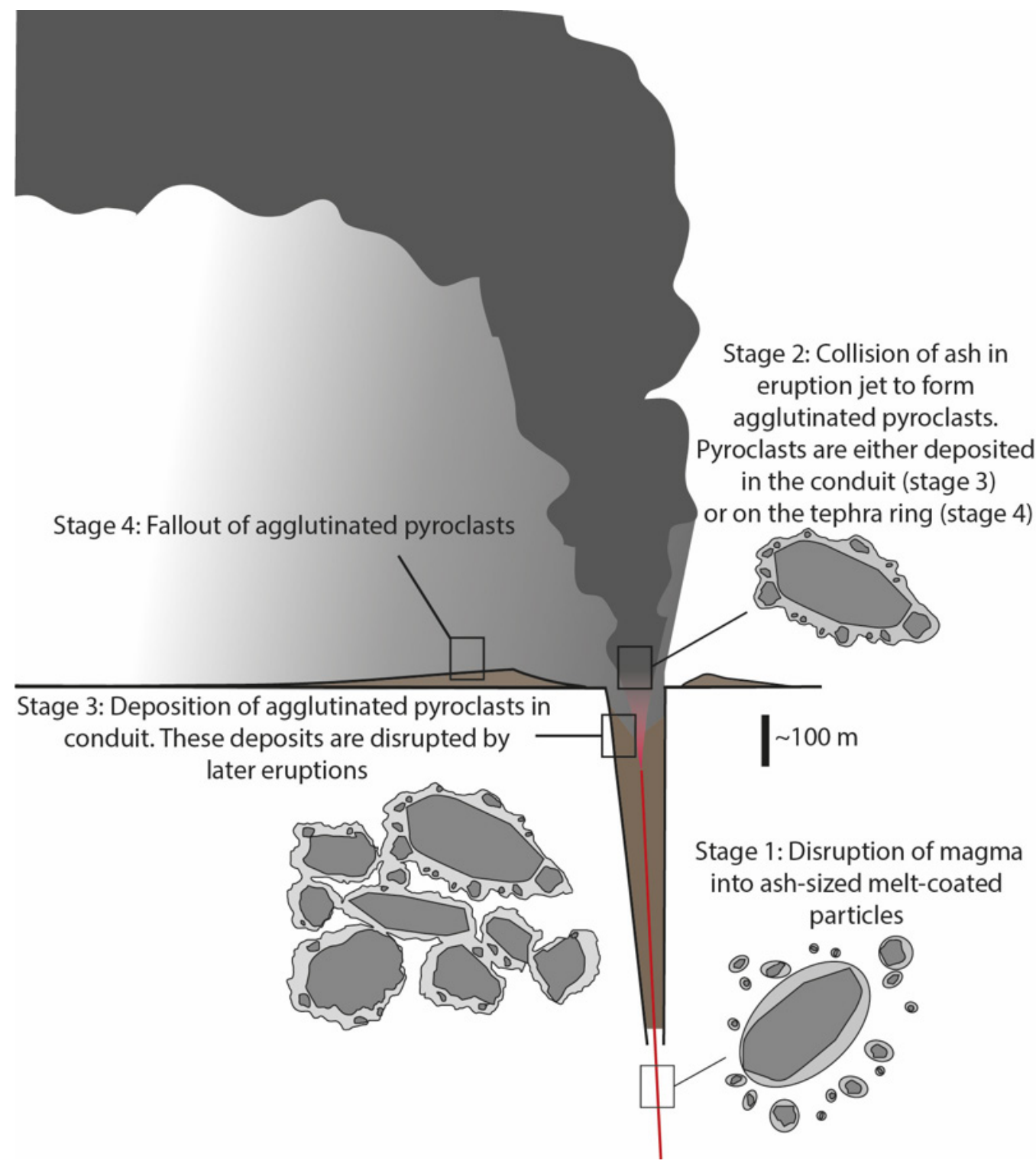

Figure 7: Genesis of agglutinated pyroclasts. Ascending magma is fragmented into ash-sized particles (stage 1) which then collide to form agglutinated pyroclasts (stage 2). These then either fallout in the conduit to form a porous agglutinated deposit (stage 3), or are dispersed by the eruption plume across the tephra ring (stage 4). Conduit deposits are disrupted by subsequent eruptions and fragments are entrained into the plume and deposited in the surrounding tephra ring. Scale bar refers to the volcanic plumbing system and edifice, not the pyroclasts.

ascent. Agglutination of small particles onto the exteriors of larger ash particles occurred via collisions in an eruption jet. Particles adhered together via limited viscous flow of melt at point contacts. Larger particles collided and agglutinated either within the eruption plume to form larger delicate and porous agglutinated pyroclasts, or upon deposition within the conduit to form an agglutinated deposit. Theoretical considerations indicate that agglutination occurred over very short timescales. We envisage that deposits in the conduits would have been periodically fragmented by successive eruptions and that those fragments were entrained into eruption plumes and then deposited in the tephra ring. The Igwisi Hills pyroclasts represent the start of an agglutination process that, if continued, could produce dense coherent welded rocks that are similar in texture to hypabyssal intrusions or lavas. They thus provide a robust template for interpreting other similar but less well-preserved rocks in kimberlite pipes elsewhere.

\section{Acknowledgements}

RJB acknowledges a National Geographic Committee for Exploration and Research grant (\#8562_08). KJD was supported by NE/M018687/1. Leon Bowen (De- 
partment of Physics, Durham University) is thanked for invaluable help on the SEM. We thank RAF Cas, LA Porritt, and four anonymous reviewers for comments on versions of this manuscript. MO Chevrel is thanked for expert editorial guidance.

\section{Author contributions}

RJB and SM conducted fieldwork and sampled the deposits. DH, RJB, TJJ, KJD, and TMG undertook laboratory and image analyses on samples. FBW contributed the section on welding regimes. All authors contributed to the development of interpretations and discussion, the writing of the paper, and the drafting of figures.

\section{Data AVAilability}

Data for Figure 6 is available on Figshare.com (https: //doi.org/10.6084/m9. figshare.8863907.v1).

\section{Copyright NOTICE}

(C) The Author(s) 2020. This article is distributed under the terms of the Creative Commons Attribution 4.0 International License, which permits unrestricted use, distribution, and reproduction in any medium, provided you give appropriate credit to the original author(s) and the source, provide a link to the Creative Commons license, and indicate if changes were made.

\section{REFERENCES}

Abràmoff, M. D., P. J. Magalhães, and S. J. Ram (2004). "Image processing with ImageJ". Biophotonics international 11.7, pp. 36-42.

Afanasyev, A. A., O. Melnik, L. Porritt, J. C. Schumacher, and R. S. J. Sparks (2014). "Hydrothermal alteration of kimberlite by convective flows of external water". Contributions to Mineralogy and Petrology 168.1. DOI: $10.1007 / \mathrm{s} 00410-014-1038-y$.

Andrews, G. D. M. and M. J. Branney (2011). "Emplacement and rheomorphic deformation of a large, lavalike rhyolitic ignimbrite: Grey's Landing, southern Idaho". Geological Society of America Bulletin 123.34, pp. 725-743. Dor: 10.1130/b30167.1.

Bassett, H. (1954). "The Igwisi craters and lavas". Records of the Geological Survey of Tanganyika 4, pp. 81-92.

Bell, K. and M. H. Dodson (1981). "The Geochronology of the Tanzanian Shield". The Journal of Geology 89.1, pp. 109-128. DOI: $10.1086 / 628567$.
Bouvard, D. and F. Lange (1991). "Relation between percolation and particle coordination in binary powder mixtures". Acta Metallurgica et Materialia 39.12, pp. 3083-3090. DoI: 10.1016/0956-7151(91)90041-x. Brett, R., J. Russell, G. Andrews, and T. J. Jones (2015). "The ascent of kimberlite: Insights from olivine". Earth and Planetary Science Letters 424, pp. 119-131. Dor: 10.1016/j.epsl.2015.05.024.

Brown, R. J., B. Buse, R. S. J. Sparks, and M. Field (2008a). "On the Welding of Pyroclasts from Very Low-Viscosity Magmas: Examples from Kimberlite Volcanoes". The Journal of Geology 116.4, pp. 354374. DOI: $10.1086 / 588832$.

Brown, R. J., T. Gernon, J. Stiefenhofer, and M. Field (2008b). "Geological constraints on the eruption of the Jwaneng Centre kimberlite pipe, Botswana". Journal of Volcanology and Geothermal Research 174.13, pp. 195-208. Dor: 10.1016/j . jvolgeores . 2007. 12.032.

Brown, R. J., S. Manya, I. Buisman, G. Fontana, M. Field, C. M. Niocaill, R. S. J. Sparks, and F. M. Stuart (2012). "Eruption of kimberlite magmas: physical volcanology, geomorphology and age of the youngest kimberlitic volcanoes known on earth (the Upper Pleistocene/Holocene Igwisi Hills volcanoes, Tanzania)". Bulletin of Volcanology 74.7, pp. 1621-1643. Dor: 10 . $1007 / \mathrm{s} 00445-012-0619-8$.

Brown, R. J., M. Tait, M. Field, and R. S. J. Sparks (2009). "Geology of a complex kimberlite pipe (K2 pipe, Venetia Mine, South Africa): insights into conduit processes during explosive ultrabasic eruptions". Bulletin of Volcanology 71.1, pp. 95-112. Dor: $10.1007 / \mathrm{s} 00445-008-0211-4$.

Brown, R. J. and G. A. Valentine (2013). "Physical characteristics of kimberlite and basaltic intraplate volcanism and implications of a biased kimberlite record". Geological Society of America Bulletin 125.78, pp. 1224-1238. Dor: 10.1130/b30749.1.

Buse, B., R. S. J. Sparks, M. Field, J. C. Schumacher, K. Chisi, and T. Tlhaodi (2011). "Geology of the BK9 kimberlite (Damtshaa, Botswana): implications for the formation of dark volcaniclastic kimberlite". Bulletin of Volcanology 73.8, pp. 1029-1045. DOI: 10 . 1007/s00445-011-0491-y.

Carey, S. and R. S. J. Sparks (1986). "Quantitative models of the fallout and dispersal of tephra from volcanic eruption columns". Bulletin of Volcanology 48.23, pp. 109-125. Dor: 10.1007/bf01046546.

Carracedo Sánchez, M., F. Sarrionandia, J. Arostegui, and J. Gil Ibarguchi (2015). "Silicate glass micro and nanospherules generated in explosive eruptions of ultrabasic magmas: Implications for the origin of pelletal lapilli". Journal of Volcanology and Geothermal Research 293, pp. 13-24. Dor: $10.1016 / \mathrm{j}$. jvolgeores . 2014.12.010.

Cas, R., P. Hayman, A. Pittari, and L. Porritt (2008). "Some major problems with existing models and terminology associated with kimberlite pipes from a 
volcanological perspective, and some suggestions". Journal of Volcanology and Geothermal Research 174.13, pp. 209-225. Dor: $10.1016 / \mathrm{j}$. jvolgeores . 2007. 12.031 .

Church, A. A. and A. P. Jones (1994). "Hollow natrocarbonatite lapilli from the 1992 eruption of Oldoinyo Lengai, Tanzania". Journal of the Geological Society 151.1, pp. 59-63. Dor: 10.1144/gsjgs.151.1.0059.

Crawford, B., C. Hetman, T. Nowicki, M. Baumgartner, and S. Harrison (2009). "The geology and emplacement history of the Pigeon kimberlite, EKATI Diamond Mine, Northwest Territories, Canada". Lithos 112, pp. 501-512. DoI: $10.1016 / \mathrm{j}$. lithos . 2009.06 . 032.

Davis, G. L. (1977). "The ages and uranium contents of zircons from kimberlites and associated rocks". International Kimberlite Conference: Extended Abstracts. Vol. 2, pp. 67-69.

Dawson, J. B. (1964). "Carbonate Tuff Cones in Northern Tanganyika". Geological Magazine 101.2, pp. 129137. DOI: 10.1017 /s0016756800048561.

- (1971). "Advances in kimberlite geology". EarthScience Reviews 7.4, pp. 187-214. DoI: 10.1016/0012$8252(71) 90120-6$.

- (1994). "Quaternary kimberlitic volcanism on the Tanzania Craton". Contributions to Mineralogy and Petrology 116.4, pp. 473-485. DOI: 10. $1007 /$ bf00310913.

Dawson, J. B. and J. B. Hawthorne (1973). "Magmatic sedimentation and carbonatitic differentiation in kimberlite sills at Benfontein, South Africa". Journal of the Geological Society 129.1, pp. 61-85. Dor: 10.1144/gsjgs.129.1.0061.

Dawson, J. B., H. Pinkerton, G. E. Norton, and D. M. Pyle (1990). "Physicochemical properties of alkali carbonatite lavas: Data from the 1988 eruption of Oldoinyo Lengai, Tanzania". Geology 18.3, p. 260. DoI: 10 . $1130 / 0091-7613(1990) 018<0260$ : ppoacl $>$ 2.3. co;2.

Ellis, B. S., B. Cordonnier, M. C. Rowe, D. Szymanowski, O. Bachmann, and G. D. M. Andrews (2015). "Groundmass crystallisation and cooling rates of lava-like ignimbrites: the Grey's Landing ignimbrite, southern Idaho, USA". Bulletin of Volcanology 77.10. DOI: $10.1007 / \mathrm{s} 00445-015-0972-5$.

Fedortchouk, Y. (2004). "Intensive Variables in Kimberlite Magmas, Lac de Gras, Canada and Implications for Diamond Survival". Journal of Petrology 45.9, pp. 1725-1745. DoI: 10.1093/petrology/egh031.

Field, M. and B. Scott Smith (1999). "Contrasting geology and near-surface emplacement of kimberlite pipes in southern Africa and Canada". Proceedings of the 7th international kimberlite conference. Vol. 1. Red Roof Design Cape Town, pp. 214-237.

Field, M., J. Stiefenhofer, J. Robey, and S. Kurszlaukis (2008). "Kimberlite-hosted diamond deposits of southern Africa: A review". Ore Geology Reviews
34.1-2, pp. 33-75. Dor: $10.1016 / \mathrm{j}$. oregeorev . 2007 . 11.002 .

Fontana, G., C. M. Niocaill, R. J. Brown, R. S. J. Sparks, and M. Field (2011). "Emplacement temperatures of pyroclastic and volcaniclastic deposits in kimberlite pipes in southern Africa". Bulletin of Volcanology 73.8, pp. 1063-1083. DoI: 10.1007 /s00445-0110493-9.

Fozzard, P. (1956). "Further notes on the volcanic rocks from Igwisi, Tanganyika". Records of the Geological Survey of Tanganyika 6, pp. 69-75.

Gernon, T., R. Brown, M. Tait, and T. Hincks (2012). "The origin of pelletal lapilli in explosive kimberlite eruptions". Nature Communications 3.1. DoI: 10. 1038/ncomms 1842 .

Gernon, T., G. Fontana, M. Field, R. Sparks, R. Brown, and C. M. Niocaill (2009). "Pyroclastic flow deposits from a kimberlite eruption: The Orapa South Crater, Botswana". Lithos 112, pp. 566-578. Dor: 10.1016/j . lithos.2009.04.016.

Gobba, J. (1989). "Kimberlite exploration in Tanzania”. Journal of African Earth Sciences (and the Middle East) 9.3-4, pp. 565-578. DoI: $10.1016 / 0899-5362$ (89) 90041-9.

Gurney, J. J., H. H. Helmstaedt, S. H. Richardson, and S. B. Shirey (2010). "Diamonds through Time". Economic Geology 105.3, pp. 689-712. DOI: 10.2113 / gsecongeo.105.3.689.

Haggerty, S. E., E. Raber, and C. W. Naeser (1983). "Fission track dating of kimberlitic zircons". Earth and Planetary Science Letters 63.1, pp. 41-50. DoI: 10 . 1016/0012-821x(83) 90020-1.

Harvey, S., B. Kjarsgaard, M. McClintock, M. Shimell, L. Fourie, P. D. Plessis, and G. Read (2009). "Geology and evaluation strategy of the Star and Orion South kimberlites, Fort à la Corne, Canada". Lithos 112, pp. 47-60. DOI: 10.1016/j . lithos . 2009. 04.040.

Hawthorne, J. (1975). "Model of a kimberlite pipe". Physics and Chemistry of the Earth 9, pp. 1-15. Dor: 10.1016/0079-1946(75)90002-6.

Howarth, G. H. and S. H. Büttner (2019). "New constraints on archetypal South African kimberlite petrogenesis from quenched glass-rich melt inclusions in olivine megacrysts". Gondwana Research 68, pp. 116-126. DoI: 10.1016/j.gr.2018.11.009.

Jones, T. J., C. D. Reynolds, and S. C. Boothroyd (2019b). "Fluid dynamic induced break-up during volcanic eruptions". Nature Communications 10.1. DOI: $10.1038 / \mathrm{s} 41467-019-11750-4$.

Jones, T. J. and J. K. Russell (2017). “Ash production by attrition in volcanic conduits and plumes". Scientific Reports 7.1. DoI: 10.1038/s41598-017-05450-6.

Jones, T. J., J. K. Russell, L. A. Porritt, and R. J. Brown (2014). "Morphology and surface features of olivine in kimberlite: implications for ascent processes". Solid Earth 5.1, pp. 313-326. DoI: 10.5194 / se-5313-2014. 
Jones, T. J., J. Russell, C. Lim, N. Ellis, and J. Grace (2017). "Pumice attrition in an air-jet". Powder Technology 308, pp. 298-305. DoI: $10.1016 / \mathrm{j}$. powtec . 2016.11.051.

Jones, T. J., J. K. Russell, and D. Sasse (2019a). "Modification of Mantle Cargo by Turbulent Ascent of Kimberlite". Frontiers in Earth Science 7. DoI: 10.3389/ feart.2019.00134.

Kurszlaukis, S. and V. Lorenz (2017). "Differences and similarities between emplacement models of kimberlite and basaltic maar-diatreme volcanoes". Geological Society, London, Special Publications 446.1, pp. 101-122. Dor: $10.1144 / \mathrm{sp} 446.5$.

Leckie, D. A., B. A. Kjarsgaard, J. Bloch, D. McIntyre, D. McNeil, L. Stasiuk, and L. Heaman (1997). "Emplacement and reworking of Cretaceous, diamond-bearing, crater facies kimberlite of central Saskatchewan, Canada". Geological Society of America Bulletin 109.8, pp. 1000-1020. DOI: $10.1130 / 0016-$ 7606 (1997) $109<1000$ : earocd $>2$. 3 . co; 2 .

Liu, E., K. Cashman, and A. Rust (2015). "Optimising shape analysis to quantify volcanic ash morphology". GeoResJ 8, pp. 14-30. Dor: 10.1016/j .grj .2015.09. $\odot \odot 1$.

Lorenz, V. (1975). "Formation of phreatomagmatic maar-diatreme volcanoes and its relevance to kimberlite diatremes". Physics and Chemistry of the Earth. Elsevier, pp. 17-27. DoI: $10.1016 /$ b978-0-08-0180175. 50006-7.

Mitchell, R. H. (1986). Kimberlites. Springer US. DoI: $10.1007 / 978-1-4899-0568-0$.

- (2008). "Petrology of hypabyssal kimberlites: Relevance to primary magma compositions". Journal of Volcanology and Geothermal Research 174.1-3, pp. 18. DoI: $10.1016 / \mathrm{j}$. jvolgeores. 2007.12.024.

Mitchell, R. H., A. Giuliani, and H. O’Brien (2019). "What is a Kimberlite? Petrology and Mineralogy of Hypabyssal Kimberlites". Elements 15.6, pp. 381386. DoI: 10.2138 /gselements.15.6.381.

Moss, S. and J. K. Russell (2011). "Fragmentation in kimberlite: products and intensity of explosive eruption". Bulletin of Volcanology 73.8, pp. 983-1003. Dor: $10.1007 / \mathrm{s} 00445-011-0504-\mathrm{x}$.

Nowicki, T., L. Porritt, B. Crawford, and B. Kjarsgaard (2008). "Geochemical trends in kimberlites of the Ekati property, Northwest Territories, Canada: Insights on volcanic and resedimentation processes". Journal of Volcanology and Geothermal Research 174.13, pp. 117-127. Dor: $10.1016 / \mathrm{j}$. jvolgeores . 2007. 12.030.

Pawlowski, L. (2008). The Science and Engineering of Thermal Spray Coatings. John Wiley \& Sons, Ltd. DoI: 10.1002/9780470754085.

Pell, J., J. K. Russell, and S. Zhang (2015). "Kimberlite emplacement temperatures from conodont geothermometry". Earth and Planetary Science Letters 411, pp. 131-141. DoI: 10.1016/j .epsl.2014.12.003.
- (2018). "Conodont geothermometry in pyroclastic kimberlite: constraints on emplacement temperatures and cooling histories". Mineralogy and Petrology 112.S2, pp. 477-490. DoI: 10.1007 /s00710-0180561-3.

Porritt, L. A. and J. K. Russell (2012). "Kimberlite ash: Fact or fiction". Physics and Chemistry of the Earth, Parts $A / B / C$ 45-46, pp. 24-32. DoI: $10.1016 /$ j.pce. 2011.03 .002 .

Porritt, L. A., J. K. Russell, and S. Quane (2012). "Pele's tears and spheres: Examples from Kilauea Iki". Earth and Planetary Science Letters 333-334, pp. 171-180. Dor: $10.1016 / \mathrm{j}$.epsl.2012.03.031.

Porritt, L. A., J. K. Russell, H. McLean, G. Fomradas, and D. Eichenberg (2013). "A Phreatomagmatic Kimberlite: The A418 Kimberlite Pipe, Northwest Territories, Canada". Proceedings of 10th International Kimberlite Conference. Springer India, pp. 97-107. DOI: $10.1007 / 978-81-322-1173-0 \_7$.

Quane, S. L. and J. K. Russell (2005). "Ranking welding intensity in pyroclastic deposits". Bulletin of Volcanology 67.2, pp. 129-143. DOI: 10.1007 / s 00445 ๑०4-0367-5.

Reid, A. M., C. Donaldson, J. Dawson, R. Brown, and W. Ridley (1975). "The Igwisi Hills extrusive "Kimberlites"”, pp. 199-218. Dor: 10.1016/b978-0-08018017-5.50020-1.

Russell, J. K., L. A. Porritt, Y. Lavallée, and D. B. Dingwell (2012). "Kimberlite ascent by assimilationfuelled buoyancy". Nature 481.7381, pp. 352-356. DoI: $10.1038 /$ nature 10740 .

Russell, J. K., R. S. J. Sparks, and J. L. Kavanagh (2019). "Kimberlite Volcanology: Transport, Ascent, and Eruption”. Elements 15.6, pp. 405-410. Dor: 10. 2138/gselements.15.6.405.

Sampson, D. N. (1953). "The volcanic hills at Igwisi". Records of the Geological Survey of Tanganyika 3, pp. $48-53$.

Skinner, E. and J. Marsh (2004). "Distinct kimberlite pipe classes with contrasting eruption processes". Lithos 76.1-4, pp. 183-200. Dor: 10.1016/j . lithos . 2004.03 .044

Soriano, C., S. Zafrilla, J. Martı, S. Bryan, R. Cas, and G. Ablay (2002). "Welding and rheomorphism of phonolitic fallout deposits from the Las Cañadas caldera, Tenerife, Canary Islands". Geological Society of America Bulletin 114.7, pp. 883-895. Dor: 10.1130/ 0016-7606 (2002) 114<0883: waropf>2 . ० . co; 2.

Sparks, R. S. J. (2013). "Kimberlite Volcanism”. Annual Review of Earth and Planetary Sciences 41.1, pp. 497528. DoI: 10.1146/annurev-earth-042711-105252.

Sparks, R. S. J., L. Baker, R. Brown, M. Field, J. Schumacher, G. Stripp, and A. Walters (2006). "Dynamical constraints on kimberlite volcanism". Journal of Volcanology and Geothermal Research 155.1-2, pp. 1848. DoI: $10.1016 / \mathrm{j}$. jvolgeores . 2006.02.010.

Sparks, R. S. J., S. R. Tait, and Y. Yanev (1999). "Dense welding caused by volatile resorption". Journal of the 
Geological Society 156.2, pp. 217-225. Dor: 10.1144/ gsjgs.156.2.0217.

Sparks, R. S. J. and J. V. Wright (1979). "Welded airfall tuffs". Geological Society of America Special Papers. Geological Society of America, pp. 155-166. Dor: 10. 1130/spe180-p155.

Stripp, G. R., M. Field, J. C. Schumacher, R. S. J. Sparks, and G. Cressey (2006). "Post-emplacement serpentinization and related hydrothermal metamorphism in a kimberlite from Venetia, South Africa". Journal of Metamorphic Geology 24.6, pp. 515-534. DoI: 10.1111/j.1525-1314.2006.00652.x.

Sumner, J., S. Blake, R. Matela, and J. Wolff (2005). "Spatter". Journal of Volcanology and Geothermal Research 142.1-2, pp. 49-65. DOI: $10.1016 / j$. jvolgeores.2004.10.013.

van Straaten, B. I., M. G. Kopylova, J. K. Russell, and B. H. Scott Smith (2011). "A rare occurrence of a crater-filling clastogenic extrusive coherent kimberlite, Victor Northwest (Ontario, Canada)". Bulletin of Volcanology 73.8, pp. 1047-1062. Dor: 10.1007 / s00445-011-0507-7.
Vasseur, J., F. B. Wadsworth, Y. Lavallée, K.-U. Hess, and D. B. Dingwell (2013). "Volcanic sintering: Timescales of viscous densification and strength recovery". Geophysical Research Letters 40.21, pp. 56585664. DOI: $10.1002 / 2013 \mathrm{gl} 058105$.

Wadsworth, F. B., J. Vasseur, E. W. Llewellin, J. Schauroth, K. J. Dobson, B. Scheu, and D. B. Dingwell (2016). "Sintering of viscous droplets under surface tension". Proceedings of the Royal Society A: Mathematical, Physical and Engineering Sciences 472.2188, p. 20150780. Dor: 10.1098/rspa.2015.0780.

Willcox, A., I. Buisman, R. Sparks, R. Brown, S. Manya, J. Schumacher, and H. Tuffen (2015). "Petrology, geochemistry and low-temperature alteration of lavas and pyroclastic rocks of the kimberlitic Igwisi Hills volcanoes, Tanzania". Chemical Geology 405, pp. 82101. Dor: $10.1016 / \mathrm{j}$. chemgeo.2015.04.012.

Wilson, L. and T. Huang (1979). "The influence of shape on the atmospheric settling velocity of volcanic ash particles". Earth and Planetary Science Letters 44.2, pp. 311-324. Dor: 10.1016/0012-821x (79) 90179- 1 . 